\title{
"This Is Called Free-Falling Theory not Culture Shock!": A Narrative Inquiry on Second Language Socialization
}

\section{Deniz Ortaçtepe}

To cite this article: Deniz Ortaçtepe (2013) "This Is Called Free-Falling Theory not Culture Shock!": A Narrative Inquiry on Second Language Socialization, Journal of Language, Identity \& Education, 12:4, 215-229, DOI: 10.1080/15348458.2013.818469

To link to this article: http://dx.doi.org/10.1080/15348458.2013.818469

曲 Published online: 04 Sep 2013.

Submit your article to this journal \lceil

Џ Article views: 805

Q View related articles $\longleftarrow$

Citing articles: 5 View citing articles 5 


\title{
ARTICLES
}

\section{“This Is Called Free-Falling Theory not Culture Shock!": A Narrative Inquiry on Second Language Socialization}

\author{
Deniz Ortaçtepe \\ Bilkent University
}

\begin{abstract}
Grounded in the framework of second language socialization, this study explores the identity (re)construction of Erol, a Turkish doctoral student in the United States. Drawn from a larger corpus collected for a longitudinal, mixed-method research, the data for this study came from autobiographies, journal entries, and semistructured interviews. Based on a synthesis of inductive-thematic analysis (Boyatzis, 1998), as well as deductive approaches through the use of three sensitizing concepts-investment (Norton, 1995), cultural capital (Bourdieu, 1977), and audibility (Miller, 2003) -Erol's social identity (re)construction was marked with struggle: first, to gain social networks and, second, to be recognized within the target language community. Erol's story, while providing evidence for the role of affective and socially structured variables in enabling language learners' access to social interactions, also draws attention to the need for more research at the discourse level to explore how power relations within speech communities influence the nature of interaction between international students and the host culture.
\end{abstract}

Key words: language socialization, social identity, investment, international students

Over the past 15 years, second language (L2) research has witnessed an expanding interest on the social aspects of language learning, one of which is the identity construction of L2 learners. In their state-of-the-art article on identity, Norton and Toohey (2011) underline that the conceptualization of identity around the 1980s conceived language learners as having "fixed identities, learning styles and motivations," while the current research on L2 identity draws from poststructural and sociocultural theories of language learning and perceives "identities as fluid, context-dependent, and context-aims producing, in particular historical and cultural circumstances" (p. 419). Following this new paradigm on L2 identity, the present study aims

Correspondence should be sent to Deniz Ortaçtepe, Bilkent University, Graduate School of Education, Bilkent, Ankara, Turkey. E-mail: denizortactepe@yahoo.com 
to explore the social identity (re)negotiation of an international graduate student in the United States.

As Norton and Toohey (2001) state, the study of successful language learners should correspond to the study of the social contexts where and through which individuals learn another language. Norton's (1995) call for L2 acquisition research to develop a "comprehensive theory of social identity that integrates language learner and the language learning context" (p. 12) has been responded to by many studies conducted after the 1990s, many of which addressed questions such as "how language learners position themselves and are positioned by others depending on where they are, who they are with and what they are doing" (Block, 2007, p. 2). Miller (2004) also elaborates on the interplay between language and social identity by suggesting that "language use is a form of self-representation" (p. 291). Therefore, learning a second language can lead to identity negotiation and can enable access to symbolic capital (Bourdieu, 1991) through participation in social and academic contexts within the target language culture. In that sense, a language learner's identity is in a state of flux due to socially mediated reactions (Ricento, 2005), the positionings of others (Davies \& Harré, 1990), and social networks (Daming, Xiaomei, \& Wei, 2008).

While there is a plethora of research on language learner identity, especially with emphasis on adult immigrants (e.g., Cervatiuc, 2009; De Fina, 2003; Norton, 2000) and English as a second language (ESL) learners (e.g., Cots \& Nussbaum, 2008; Miller, 1999; Talmy, 2008), the present study is distinctive from previous research since it combines three different research interests: second language socialization, international students, and social identity. Previous studies in the field either focused on international students' identity negotiation with no reference to their language socialization (e.g., Burnapp, 2006; Haugh, 2008; Koehne, 2006) or examined students' academic (discourse) socialization in higher education institutions (e.g., Angelova \& Riazantseva, 1999; Nam, 2008; Noji, 2003). The present study expands the scope of previous research by employing a language socialization approach that emphasizes the social identity negotiation of international students across all contexts they engage in during their long-term stay abroad. The rationale behind adopting an L2 socialization approach is twofold: first, to identify the social and academic contexts that international students are involved in as well as to understand "how persons become competent members of social groups and the role of language in this process" (Schieffelin \& Ochs, 1986, p. 167) and, second, to explore how their L2 socialization processes enable them to (re)construct their social identities in relation to the new sociocultural world in which they are positioned as newcomers.

\section{THEORETICAL FRAMEWORK}

\section{Second Language Socialization and Social Identity}

As an interdisciplinary approach that has its roots in anthropology, sociolinguistics, developmental psychology, and sociology (Schieffelin \& Ochs, 1986), language socialization explores "how language practices organize the life span process of becoming an active, competent participant in one or more communities" (Ochs, 2001, p. 227). The literature on L2 socialization can be divided into two areas: studies investigating linguistic aspects, such as language maintenance and shift (e.g., di Lucca, Masiero, \& Pallotti, 2008; Schecter \& Bayley, 2004) as well as pragmatic 
development (e.g., Kanagy, 1999; Matsumura, 2001; Ohta, 1999), and studies that focus on social aspects such as identity (see Kinginger, 2009, for a review of studies in this field). The relationship between second language socialization and identity lies in the fact that when newcomers enter the target language community, their participation and acceptance in the communities of practice may vary from limited or no participation to growing involvement (Norton, 2000), which, as a result, changes the social roles and relationships inhabited by the newcomers in the new society (Ochs, 2002).

Previous studies on L2 learners' social identity focused on three important notions: Norton's (1995) investment, Miller's (2003) audibility, and Bourdieu's (1977) cultural capital. Cultural capital, which is the baseline for the other two sensitizing concepts, refers to the knowledge and modes of thought that pertain to specific classes and groups in relation to sets of social forms (Bourdieu, 1977). Miller's (2003) notion of audibility, which builds on Bourdieu's cultural capital, can be explained as "the degree to which speakers sound like, and are legitimated by, users of the dominant discourse" (Pavlenko \& Blackledge, 2004, p. 24), since legitimacy in a language "derives from the cultural and symbolic capital of the speaker and the listener" (Miller, 2003, p. 47). Norton (1995) also expands on Bourdieu's cultural capital to explain her notion of investment, a concept that connects language learners to the social world. According to Norton (1995), "if learners invest in a second language, they do so with the understanding that they will acquire a wider range of symbolic and material resources, which will in turn increase the value of their cultural capital" (p. 17). Thus, Norton's notion of investment perceives language learning as an investment on the part of language learners to acquire a wide range of symbolic and material sources.

\section{Social Identity and International Students}

A closer look at the studies that examined identity within the framework of language socialization would reveal that these studies were concerned with study-abroad students rather than international students. The distinction between international and study-abroad students or sojourners is important because the former, being enrolled in the institutions of higher education in the host culture, not only spend more time abroad but also might continue their stay abroad even after the end of their studies (Wan, 1990). On the other hand, study-abroad students as "relatively shortterm visitors" (Wan, 1990, p. 13) are enrolled in a higher education institution in their home cultures and, therefore, know that their stay in the host culture is only temporary. Therefore, the purpose and length of stay in the host culture influence the language socialization processes that international and study-abroad students go through (Ortaçtepe, 2012). For instance, the studies of Polanyi (1995) and DuFon (2006) examined the participants' trajectory of study abroad for a semester, while Wilkinson's (2002) and Churchill's (2006) participants' length of stay in the host culture was only a month. Only Siegal's (1996) and Murphy-Lejeune's (2002) studies dealt with sojourners on a longitudinal basis, the former focusing on the destructive effects of the participant's (a Western woman learning Japanese) positioning as a foreigner within the host culture, while the latter explored the issue of student mobility within the European Union. As these studies indicate, there is a need for L2 socialization research to address the issue of the social identity negotiation of international students whose needs and interests are different from short-term sojourners. 
Montgomery's (2010) ethnographic study, addressing the above-mentioned gap in the literature, provides a comprehensive analysis of the lived experiences of international students in the United Kingdom. Yet, attention needs to be paid to those international students in the United States, since the United States is the No. 1 country to attract international students with a record high number of 764,495 enrollments (Institute of International Education, 2012). Of interest, while there is an abundance of literature examining the Western study-abroad students (e.g., Churchill, 2006; Hassall, 2006; Kinginger, 2004; Wilkinson, 2002), to the knowledge of the researcher, there is no study that focuses on the social identity construction of international students in the United States from a language socialization perspective. For this reason, this study aims to fill this gap in L2 socialization research by exploring the social identity negotiation of a Turkish international student pursuing a doctoral degree in the United States.

\section{METHOD}

The data discussed in this article are drawn from a larger corpus collected for a longitudinal, mixed-method study with eight Turkish graduate students in the United States. While the larger study that followed the language-socialization processes of the participants for over a year combined the linguistic and social development of the participants through quantitative and qualitative techniques, respectively, the present study, by focusing on the language socialization trajectory of one participant vis-à-vis his social identity reconstruction, answers Lantolf and Pavlenko's (2001) call for “robust and detailed case studies documenting the activities of people on the periphery of linguistic communities of practice and how they gain or are denied (full) participation in these communities" (p. 155).

The present study relies on a narrative case-study design. First, the case of Erol (the participant) was a "telling case" (Mitchell, 1984) among the other participants, since his story of language socialization was not only unique but also "information rich" (Patton, 2001); hence, his case serves to exemplify the trajectories of international students and their identity (re)construction. Second, narrative inquiry not only sheds light on the lived experiences of international students, but also provides a rich source of data from which to explore language socialization (Pavlenko, 2008) since "interest in identity and socialization is an inevitable outcome of listening to learners' stories" (Kinginger, 2009, p. 155). In other words, this study does not perceive narrative inquiry as solely a data collection method for "factual data subject to content analysis" (Pavlenko, 2002, p. 214); narrative inquiry is also a discursive construction to "uncover multiple sociocultural, sociohistorical, and rhetorical influences that shape narrative construction" (p. 217). Thus, a narrative approach is adopted in order to gain insights into the participant's language socialization as well as the nature of those stories in terms of how they are being told, why they are being told in a particular way, and what untold stories remained, if any. Hence, the present study is a narrative case study that aims to explore the social identity construction of Erol, a Turkish international student, through his lived experiences of language socialization in the United States. The overarching research question that guides this study is What are the reflections of a Turkish international student's L2 socialization in the United States on his social identity negotiation? 


\section{Data Collection}

The data for this study came from three different instruments: journal entries (including one autobiographical narrative), interviews, and follow-up e-mail exchanges. Since the present study adopted a longitudinal design, the data collection through the journals and interviews took place three times throughout the 2009-2010 academic year (see Figure 1 below).

The first journal entry, an autobiographical narrative, was used to shed light on the participant's history of learning English (Pavlenko, 2008) and the story behind his coming to the target language country, the United States. The second and third journal entries, on the other hand, revealed insights into the participant's socialization processes, the social contexts he was involved in, as well as how he perceived himself in the target-language culture. The second and third journal entries were prompted in the sense that the participant was asked to write about his social experiences in the United States (e.g., an unpleasant incident, a surprising incident).

Each journal entry was followed by semistructured interviews that were designed according to Seidman's (1998) three-part interview design comprising past, present, and future. The first interview (past) focused on the participant's aspirations, history, and life circumstances. This part was conducted during the first data collection phase as a complement to the autobiographical journals. The second interview dealt with issues related to the participant's present situation: what he was doing in the United States, what roles he has taken, who he has had contact with, what social situations he was involved in, and how he perceived himself in those situations. Finally, the third interview addressed his future expectations from his life in the United States as well as an overall discussion on what has been discussed and left out in his story of language socialization. Interviews were audiotaped and then transcribed for data analysis. Each data collection phase was pursued by follow-up e-mail exchanges, which not only served member checking so as to increase the credibility of the narrative account (Creswell \& Miller, 2000) but also made the data collection an ongoing process through which the researcher gained a rich description of the participant.

\section{Data Analysis}

The data analysis consisted of two major steps. First, the qualitative data coming from journal entries, interviews, and follow-up e-mail exchanges were analyzed according to Boyatzis's (1998) thematic analysis in order to explore the participant's language socialization trajectory in the United States. The broad themes that emerged from the thematic analysis were araf, gurbet,

\begin{tabular}{|c|c|c|c|c|c|c|}
\hline $\begin{array}{l}\text { Data } \\
\text { Collection }\end{array}$ & $\begin{array}{c}1^{\text {st }} \text { Phase: } \\
\text { October, } 2009 \\
\end{array}$ & & $\begin{array}{c}2^{\text {nd }} \text { Phase: } \\
\text { February, 2010 } \\
\end{array}$ & & $\begin{array}{l}3^{\text {rd }} \text { Phase: } \\
\text { June, } 2010 \\
\end{array}$ & \\
\hline Instruments & $\begin{array}{c}\text { Autobiographical } \\
\text { Narrative } \\
\text { Interviews }\end{array}$ & $\begin{array}{c}\text { Follow-up } \\
\text { e-mails } \\
\longrightarrow\end{array}$ & $\begin{array}{l}\text { Journal Entries } \\
\text { Interviews }\end{array}$ & $\begin{array}{c}\text { Follow-up } \\
\text { e-mails } \\
\longrightarrow\end{array}$ & $\begin{array}{l}\text { Journal } \\
\text { Entries } \\
\text { Interviews }\end{array}$ & $\begin{array}{c}\text { Follow-up } \\
\text { e-mails } \\
\longrightarrow\end{array}$ \\
\hline
\end{tabular}

FIGURE 1 Data collection procedure and instruments. (Color figure available online.) 
and free falling. Second, sensitizing concepts, that is, "points of departure to form interview questions, to look at data, to listen to interviewees, and to think analytically about the data" (Charmaz, 2006, p. 17), were employed as analytical tools to understand Erol's (re)construction of social identity. Thus, this study adopted the sensitizing concepts mentioned in the literature review (Norton's [1995] investment, Miller's [2003] audibility, and Bourdieu's [1977] cultural capital), as starting points to see how Erol, as a Turkish doctoral student in the United States, negotiated his social identity by using the target language in the many different discourses he was involved in. While the data-driven themes through an inductive thematic analysis (Boyatzis, 1998) shed light on Erol's language socialization process in the United States, the sensitizing concepts revealed insights into his identity negotiation.

\section{FINDINGS AND DISCUSSION}

In order to answer the overarching research question, What are the reflections of a Turkish international student's L2 socialization in the United States on his social identity negotiation? first, Erol's language-socialization trajectory will be described in relation to the themes that emerged in the thematic analysis; next, his identity negotiation will be explored in reference to the sensitizing concepts adopted by this study.

\section{Erol's Language Socialization in the United States}

Kramsch (2009) posits that "desire in language learning is the basic drive toward self-fulfillment ... the urge to escape from a state of tedious conformity with one's present environment to a state of plenitude and enhanced power" (p. 14). It was this kind of desire that enabled Erol to embark on a journey to the United States. Being tired of his work experience in Turkey, Erol decided to pursue a doctorate degree abroad. He was never an academic person, yet he was interested in research, so he decided to give it a chance and undertake a doctorate degree abroad. He applied to the ad he saw posted at his college campus in Turkey, which turned out to be an ad for the school that he is now enrolled in. However, a month after his arrival, Erol realized that his department did not offer him an advisor who worked within his fields of interest. In other words, the time period that Erol designated for being in the United States would not enable him to achieve his purposes: the pursuit of an academic life. Yet, the feeling of "What is going to happen when I go back? Nothing. You will go back before fixing anything" kept him in the States, while leading to a period of, what he calls, araf.

Araf. In its religious sense, araf is the place between heaven and hell; in Turkish common sense, araf refers to being stuck in-between. This was a metaphor Erol picked up from Elif Shafak's (2004) novel titled araf in Turkish (English title, The Saint of Incipient Insanities), a book that tells the story of a Turkish doctoral student in the United States. Hence, Erol's feeling of being stuck in between the United States and Turkey, and not being able to choose one or the other, made him feel like he was in araf: He was neither here in the United States nor there in Turkey. Erol stated: 
I was so sick and tired of the work environments in Turkey. I was feeling trapped. Someone opened the Pandora's box and said go wherever you can. Now I ponder upon things . . . because it is not what it seems to be . . . yet I can't go back into that box, going back to Turkey doesn't make sense at all, I wasn't happy over there either ... so this is araf. . . .

One of the aspects of araf for Erol was the feeling of detachment from his social networks in Turkey, especially from his friends. Erol's weakening relationship with his friends in Turkey resonates with the idea that international students' moving away from home to study abroad is similar to the experience of individuals who have moved within their home country, since their strong ties with family and friends in the immediate context in their home countries are replaced with the weaker ties of new friendships (Montgomery, 2010). In a similar way, Erol's main problem was being unable to establish social ties within the host culture that approximated the ones he had in Turkey. Hence, not only were Erol's social ties in Turkey diminishing, but in the United States, he was also struggling to establish new social networks to help him adapt to his new surroundings.

Gurbet (Being abroad). During the second interview Erol noted, "You know, you are conducting this study, who is going to understand it? If they have never been to gurbet? And gavur (foreigners, i.e., Americans) don't even have that concept! There's no way they can understand!"

In Turkish, gurbet refers to abroad. In other words, if someone is abroad, that means, $\mathrm{s} / \mathrm{he}$ is at gurbet. However, the English translation for "being abroad" does not really reflect all the connotations of the Turkish word gurbet, since the latter is associated with missing one's own country. Therefore, short, vocational trips to other countries do not count as gurbet, but working, studying, or living in another country for many years, do.

I looked for it a lot, a word to describe gurbet. They don't know that feeling. There's "foreigner" but it does not have that connotation. They always live by themselves and they are always on the move, yet never mention a feeling like that. I talked to someone who couldn't find a job here so went to Korea to teach English. . . . He tells me how beautiful Korea or Thailand is. That's the dominant feeling he has.

It is interesting to note that Erol's inability to share his feelings of gurbet with anyone from the host culture did not incite him to turn to compatriot association, which is the Turkish community around him. Montgomery (2010) suggests that most international students establish close relationships with people of their own nationality, not only because they have more in common with them, but also because they share similar difficulties. However, Erol refused to be involved in the Turkish community in his city. His attitude towards the Turkish community was more in the direction of separation rather than integration, since he thought he "did not have anything in common" due to "lack of meaningful communications." Erol noted that his interactions with the other Turkish people as well as with the Americans around him were superficial: "With some of them, it's like 'how you doing?' 'What's going on?' Same conversations with the Americans. . . So superficial." Erol's attitudes toward the Turkish people in his city reflect the insights of Montgomery (2010), who underlines the importance of "the almost arbitrary nature of their close relationships with their home countries" (p. 87). Erol expressed a similar form of arbitrariness in his observation that: "I would not be friends with those people if we were all in Turkey." For Erol, just sharing the same nationality or cultural background was not a reason to 
make friends with the other Turkish people, since he was looking for meaningful interactions in his relationships.

While Erol kept his distance from the Turkish community around him, he found himself close to his ex-roommate, who was also an international student from Palestine. Erol's positive attitude towards his roommate was a result of two main factors: (a) sharing cultural similarities and (b) the connection between them that emerged from their shared status as international students.

He's from the Middle East so he's like us. Therefore, not knowing the language is not a big deal with him, we understand each other. Elif Safak's book tells the story of two graduate students, both from Muslim countries. It says, even if two international students didn't know a word in another language, these two can still understand each other . . . our situation's the same. For example, a few days back I was telling him something, I meant to say damak tadi (palate) and even if I couldn't, I said "taste of mouth" - so silly but he got it.

While Erol felt more at ease with his ex-roommate, his interactions with American people have always been limited for two main reasons. First, sociocultural differences played a major role since Erol believed that American people did not really care for other international students: "This guy [his new roommate] walks around in his room all the time, he moved in 15 days ago, and I bet he doesn't know my name. I'm a 100\% sure he doesn't know my name." Erol also found it interesting that in almost all of the conversations he participated in, no one was interested in his cultural identity. For example, while he was having a conversation with an American person, the person left without saying anything, and Erol noted that it is "just like you didn't exist at all! Or they just talk amongst themselves; you just sit there and listen."

Erol's interactions with the host culture confirms Norton's (2000) argument that naturalistic language learning is not an ideal process, since the native speakers in naturalistic settings avoid interacting with the nonnative speakers, as opposed to the assumption that they would provide input and help nonnative speakers negotiate meaning in the target language. Cervatiuc's (2009) study examining the linguistic and cultural identity formation of adult immigrants in Canada suggests that having limited opportunities to practice English within limited and socially constructed contexts leads many immigrants to "become marginalized, introverted, and sensitive to rejection" (p. 255). Similarly, having limited access to social networks in the American culture, Erol, most of the time, preferred to be alone rather than "having meaningless interactions" with other people. Hence, lack of social networks and feelings of loneliness led him to a state of "free falling," a theory he developed to describe his trajectory in the United States.

Erol's "free-falling theory." Erol's free-falling theory is a multifaceted phenomenon that results from feeling uncertainty in regard to his academic studies, from being at gurbet, and from a lack of social networks to replace the weakening relationships he left behind. Erol explains his theory of free falling as follows:

The first few months you don't really know what's going on. It's the survival period. You buy a car, enroll in classes, figure out where the market is, etc. The following three months, you start missing Turkey. You don't enjoy anything. . . . One day I decided to go back, I was about to buy my one-way ticket home. Then I thought, "what's going to happen if I go back?" This question makes you stay. Then came the period of feeling nothing ... when I started staring at the walls for hours. Nothing was fun. That is when I developed the "free-falling theory" . . y you can feel OK that day, not happy but OK, you may even say "I will study today," but there's no guarantee, that's why, it's called 
“free-falling theory"- - you don't feel like doing anything, you feel like you have no energy, just boredom.

The language myth (Pellegrino, 1998), the idea that spending time abroad will result in linguistic and cultural development, was also influential in his state of "falling free." Similar to many students who go abroad to improve their second/foreign language, Erol expected that living in the target language culture and having interactions with the American people would lead to significant gains in his language proficiency. However, his visit to a Turkish friend, who had been in the United States for five years, enabled him to reconsider his expectations, while leading to a state of free falling once again:

I was thinking, he's been here so long; he's been Americanized, but no way! Not even close! We went to one of his colleagues' place to have dinner and at the end of the night when we were about to leave he said "let's go slowly slowly." You know in Turkish we say "yavas yavas (slowly slowly) gidelim (let's go)." This guy has been here for five years and look at what he says!

This example accords with the idea that the link between integration and proficiency, as suggested by the sociopsychological paradigm of second language acquisition, is weak because of the complex relations that the target-language community offers to the language learner (Pavlenko \& Blackledge, 2004). In Erol's case, his friend's language behavior and limited social networks illustrated that spending time in the target-language culture guaranteed neither supportive social networks that involve target-language speakers nor proficiency in the target language skills.

The free-falling theory that Erol developed to define his language socialization process also provides significant implications to Schumann's (1986) notion of acculturation, which refers to "the social and psychological integration of the individual with the target language (TL) group" (p. 379). Erol made a distinction between Schumann's (1986) notion of culture shock and his free-falling theory:

Some people call this phenomena "culture shock" but it's not culture shock, it's free falling. You are not exposed to any culture, you don't talk to anyone, why would it be culture shock? . . This is not culture shock because in this theory, you're departed from all your old habits, old life-and that emptiness. There's no meaning in life.

As presented above, Erol's language socialization in the United States was marked by his feelings of araf and gurbet, which eventually led him to a state of free falling. The next section will explore the reflections of his language socialization in the United States on his identity negotiation, with the help of the sensitizing concepts adopted in the study.

\section{Erol's Identity Negotiation in Terms of Sensitizing Concepts}

Audibility. As one of the sensitizing concepts adopted in this study, audibility refers to the degree to which language learners are considered legitimate speakers of the target language (Miller, 2003, 2004). Erol's attitude toward his own English was one of the factors keeping him distant from the host culture. Erol noted that his problem with English was not in academic English but to use the language in daily conversations. However, lack of meaningful relationships made it even more difficult for him to use the language in social contexts. The three instances 
below demonstrate "what he did" or "did not do" to speak English and when he really enjoyed it and found it meaningful.

1. A few days back, a black guy knocked on my door, I didn't quite get what he wanted, and I guess he wanted me to subscribe to a journal. He went on and on. I just stared at him ... He eventually asked me whether I spoke English, and I said no, so he left (laughs). Why would I talk to him? I don't understand him.

2. There are many students associations on campus as well as the religious ones. You know, they have table stands, and talk about nonsense. I know he talks nonsense; it was I guess related to continuity. This guy claimed that he could explain it with religious references. Yet, I talked to this guy for a while.

3. I drove 300 miles to a city to listen to Pink Martini live. During the concert, I was sitting next to a 70-year-old lady. My seat was in between hers and her friend's, so I suggested her to take my seat. She was like, "Oh you have an accent." Then we started talking. She grew up in Germany during WW2. She told me how she, as a German person, got married to an American guy at that time. She asked, "Are you happy in the United States? I know it must be difficult." I totally admired her. You know Americans don't touch you that much, but this lady gripped my arm when saying goodbye. I can't tell you how much I enjoyed talking to that lady that night.

These three instances provide examples for how Erol rejects speaking English when he (a) does not understand the other person, (b) engages in conversations just for the sake of speaking English, and (c) actually enjoys speaking English when it is meaningful. The third instance, in this respect, is a good exemplar of what Erol means by meaningful communication. For Erol, one of the features of "meaningful interaction" is reciprocity; the other person's being interested in his story. According to Norton (1998), "Language educators cannot take for granted that those who speak regard those who listen as worthy to listen, and that those who listen regard those who speak as worthy to speak" (p. 16). In that sense, Erol's need for reciprocity is what Norton (1998) refers to as being worthy of listening and speaking to. In those instances where Erol enjoyed speaking English, he not only found the other person "being worthy to speak to," but the other person felt the same way and found Erol "being worthy to listen to." Therefore, Erol's feeling of reciprocity resonates with Miller's (2003) notion of audibility, which is constructed through the collaboration between the speaker and the listener. The fact that the German lady not only empathized with Erol but also shared her own experiences of gurbet with him enabled them to socially construct a meaningful interaction that was built on their shared experiences.

Cultural capital. Lack of socialization with the target language speakers was not only reflected in Erol's audibility but also in his cultural capital, which refers to cultural goods, modes of thought, and social forms (Bourdieu, 1977). Erol stated that he would like to speak like a native speaker; but what he meant by speaking like a native speaker was not only speaking fluently but also understanding cultural, historical, and political references. However, according to Erol, speaking like a native speaker could only help him while he was watching TV or making phone calls, since he did not have any one in his life to interact with in English.

The importance of Erol's connection between language and social networks is twofold. First, Erol was aware that cultural capital leads to verbal facility as well as general cultural awareness 
(Bourdieu, 1977). Second, he knew that he could use cultural capital to engage in social interactions with the target-language speakers. However, what he was not aware of was the idea that "culture can become a power source" (Swartz, 1997, p. 75) to exercise communication and social interaction. Not having access to any social networks, Erol felt that this cultural capital would not change much in his life with respect to his socialization with the target-language speakers. On the contrary, having access to cultural capital could increase Erol's audibility and ease his communication as well as his integration into the target language community.

Investment. Norton's (1995) notion of investment perceives language learners "as having a complex social identity and multiple desires" (pp. 17-18). As mentioned earlier, Erol's main investment in the United States revolved around having a better life, something better and different than what he used to have in Turkey. This new life, which was initiated by his enrollment in the doctoral program, entailed not only academic socialization and excellence but also gaining access to new social networks, and speaking another language to engage in meaningful interactions. However, Erol, having problems in his academic studies, also started to face challenges in the nonacademic spheres of his new life in the States. Five months after the last interview, Erol wrote the following e-mail:

There was a big Turkish community get-together here. . . . Every time I do something with the Turkish community, I feel awful the next day. That's why I am not feeling well today. . . . I have been here for this many months, yet I don't have a social life. I was like you're fooling yourself by hanging out with Turkish people. And most of them are here for only one year, they are not going to be here forever like me. Besides, there were a few Americans in the same party, but I didn't feel like talking to them. I was like, what would it change, if I talked to these guys or not. I don't understand the function of "small talk." I still have problems in English but this is something else. I was always into other cultures, styles, people. . . I have adopted the idea of, what gavur calls "critical thinking" and other version of this concept, postmodernism. . . Not much changed in this since I came. What has changed is how gurbet made me suffer. This pain doesn't look like it's ever going to go away. . . . I haven't really interacted with an American person yet. If you add all the time I interacted with someone, it wouldn't exceed 20 to 30 hours. This is not enough to know a person let alone getting to know a culture. Long story short, I am short of socialization here. . . . And this is the end of our story.

Erol's last e-mail summarizes most of the themes that were raised earlier in this study in regard to his trajectory of language socialization in the United States. To begin with, gurbet and free falling were still persisting in Erol's story, although free falling was causing less hardship for him. Since Erol decided to stay and continue his doctoral degree, the feeling of araf seems to have been replaced with the conundrum of hanging out with Turkish people versus being alone. He longed for a social life in the United States, and he believed that in order to get to know the American culture as well as to improve his English, he needed to enhance his social networks. Kinginger (2004) underlines that

Learners have differential access to the social networks providing opportunities for engagement in the interactions so crucial to language development. Access to language is shaped not only by learners' own intentions, but also by those of the others with whom they interact-people who may view learners as embodiments of identities shaped by gender, race, and social class. (p. 221) 
In this respect, Erol's weak in-group identification with the Turkish community in the United States contributed to his feelings of loneliness and gurbet, and eventually led to a state of free falling. Kanno and Norton (2003) state that "humans are capable of connecting with communities that lie beyond the local and immediate and that investment in such imagined communities strongly influences identity construction and engagement in learning" (p. 247). Yet, the difference between Erol's real and imagined communities (Kanno \& Norton, 2003) was disparate, his investment for coming to the States was not fulfilling, and his lack of necessary resources to gain access to the imagined community was hampering his language socialization in the United States.

\section{CONCLUSION}

This study examined a Turkish doctoral student's (re)construction of social identity as a result of his trajectory of language socialization in the United States. The findings illustrate that Erol's language socialization was not as smooth as he expected and his investment in "something better" was challenged by his feelings of araf, gurbet, and "free falling." His being abroad, his weakening relationships in Turkey, and his lack of meaningful relationships in the States all led to the feeling of free falling, a theory Erol developed as an alternative to Schumann's (1997) culture shock. His negotiation of social identity was a reflection of the struggle to engage in meaningful relationships in order to gain access to the cultural sources (cultural capital) that would enable him to be accepted as a legitimate speaker (audibility). Hence, his investment as a doctoral student revolved not only around academic development but also around the social development through which he could participate in different social networks and/or communities of practices. Consequently, this study has certain implications for international students from the perspectives of language learning as well as socialization in the target-language culture.

According to Cervatiuc (2009), good L2 learners not only "refuse to be marginalized by the NS [native speaker] group for imperfect mastery of the target language" by the help of self-motivation but they also "seize opportunities to practice the target language and believe in the strength and value of their cultural capital" (p. 266). As evidenced by his last e-mail, Erol was experiencing social marginalization not only within the host culture but also in his home culture. In other words, Erol neither belonged to the Turkish people around him nor to the American culture. He did pursue opportunities to talk to native speakers "just to improve his English" but gave up at some point since his interactions did not move beyond small talk, let alone enabling him to establish meaningful relationships. In that sense, Erol's case illustrates that participation in informal contexts is voluntary, since "individuals can either participate or not in informal acquisition contexts" (Gardner \& MacIntyre, 1923, p. 213). Norton (2000) proposes that affective factors such as motivation or being extroverted, as opposed to introverted, could be related to socially constructed variables such as inequitable power relations. Hence, the interplay of these affective and socially structured variables determine language learners' access to social interactions that provide them opportunities to negotiate meaning as well as identity (Kinginger, 2004; Norton, 2001). In this respect, Erol's case, while providing evidence for Norton (2000), also draws attention to the need for more research at the discourse level in order to explore how power relations influence the nature of interactions between language learners and target-language speakers. Thus, Erol's story supports Cervatiuc's (2009) assertion that success in language learning relies on a "twofold 
social action paradigm in which the society and learners have joint ownership and investment" (p. 268).

This study's findings also concurred with the studies of Wilkinson (2000), Pellegrino (1998), and Hassall (2006) in the sense that interaction with the target-language speakers should not be taken for granted when short-term study abroad or longer-stay international students set out on a journey to a country where the target language is spoken. Sometimes no matter how hard one wants to make friends from the host culture, the lack of "meaningful relationships" could be a factor that hinders that process. Similar to the studies of Wilkinson (2000) and Pellegrino (1998), the findings of this study reject the assumption that low motivation in learning the target language can result in lack of interactions with the host culture. As evidenced by the story of Erol, who was quite motivated to improve his English, attributing the lack of social interactions with the host culture to low motivation might lead to misinterpretations resulting from underestimating the role of social factors and other individual factors. For instance, during the first few months of his stay, Erol engaged in interactions with random people he met on campus "just for the sake of speaking English." However, he soon realized that these "small talks or superficial interactions" did not help him improve his language skills since it was the same discourse in each one of these conversations; moreover, these conversations did not constitute meaningful communication. Erol's case therefore disaccords with Schumann (1997) and Hassall (2006), who perceive that motivation is the key to learning language. They argue that motivation stimulates the sojourner to seize every opportunity to interact with the target-language speakers, even if it is just for the sake of learning the language. This view presents an inauthentic approach to using the language, given that the primary function of any language is to enable communications with those who can speak it. In other words, expecting international students to engage in social interactions just for the sake of speaking and practicing the target language would only provide them with limited conversational discourses; furthermore, these discourses lack the primary function of using a language, thereby, leading the students to retreat from these opportunities unless meaningful communication can be established. Therefore, surface level attributions for lack of social interactions with the host culture (e.g., low motivation, laziness, or lack of discipline) far from explain the phenomenon that takes place between international students and the larger society. In this respect, the findings of this study call for more case studies that would provide in-depth analyses of international students' language socialization, as a means to understand the interplay of language, culture, and socially constructed variables (such as social identity) that determine the positioning of these newcomers in the target-language culture.

\section{REFERENCES}

Angelova, M., \& Riazantseva, A. (1999). "If you don’t tell me, how can I know?": A case study of four international students learning to write the U.S. Way. Written Communication, 16, 491-525.

Block, D. (2007). Second language identities. London, UK: Biddles.

Bourdieu, P. (1977). The economics of linguistic exchanges. Social Science Information, 16, 645-668.

Bourdieu, P. (1991). Language and symbolic power. Cambridge, UK: Polity Press.

Boyatzis, R. E. (1998). Transforming qualitative information: Thematic analysis and code development. Thousand Oaks, CA: Sage.

Burnapp, D. (2006). Trajectories of adjustment of international students: U-curve, learning curve, or third space. Intercultural Education, 17(1), 81-93. 
Cervatiuc, A. (2009). Identity, good language learning, and adult immigrants in Canada. Journal of Language, Identity, and Education, 8, 254-271.

Charmaz, K. (2006). Constructing grounded theory: A practical guide through qualitative analysis. London, UK: Cromwell Press.

Churchill, E. (2006). Variability in the study abroad classroom and learner competence. In M. A. DuFon \& E. Churchill (Eds.), Language learners in study abroad contexts (pp. 203-227). Clevedon, UK: Multilingual Matters.

Cots, J. M., \& Nussbaum, L. (2008). Communicative competence and institutional affiliation: Interactional processes of identity construction by immigrant students in Catalonia. International Journal of Multilingualism, 5(1), 17-40.

Creswell, J. W., \& Miller, D. L. (2000). Determining validity in qualitative inquiry. Theory Into Practice, 39(3), 124-130.

Daming, X., Xiaomei, W., \& Wei, L. (2008). Social network analysis. In L. Wei. \& M. G. Moyer (Ed.), The Blackwell guide to research methods in bilingualism and multilingualism (pp. 263-274). Singapore: Blackwell.

Davies, B., \& Harré, R. (1990). Positioning: The discursive production of selves. Journal for the Theory of Social Behaviour, 20, 43-63.

De Fina, A. (2003). Identity in narrative: A study of immigrant discourse. Philadelphia, PA: John Benjamins.

DuFon, M. A. (2006). The socialization of taste during study abroad in Indonesia. In M. A. DuFon \& E. Churchill (Eds.), Language learners in study abroad contexts (pp. 91-119). Clevedon, UK: Multilingual Matters.

Gardner, R. C., \& MacIntyre, P. D. (1992). A student's contributions to second-language learning. Part I: Cognitive variables. Language Teaching, 25, 211-220.

Hassall, T. (2006). Learning to take leave in social conversations: A diary study. In M. A. DuFon \& E. Churchill (Eds.), Language learners in study abroad contexts (pp. 31-58). Clevedon, UK: Multilingual Matters.

Haugh, M. (2008). The discursive negotiation of international student identities. Discourse: Studies in the Cultural Politics of Education, 29(2), 207-222.

Institute of International Education. (2012). Open doors report. Retrieved from http://opendoors.iienetwork.org/

Kanagy, R. (1999). Interactional routines as a mechanism for L2 acquisition and socialization in an immersion context. Journal of Pragmatics, 31, 1467-1492.

Kanno, Y., \& Norton, B. (2003). Imagined communities and educational possibilities: Introduction. Journal of Language, Identity, and Education, 2, 241-249.

Kinginger, C. (2004). Alice doesn't live here anymore: Foreign language learning and identity reconstruction. In A. Pavlenko \& A. Blackledge (Eds.), Negotiation of identities in multilingual contexts (pp. 219-242). Clevedon, UK: Cromwell Press.

Kinginger, C. (2009). Language learning and study abroad: A critical reading of research. Hampshire, UK: Palgrave Macmillan.

Koehne, N. (2006). (Be)Coming, (Be)Longing: Ways in which international students talk about themselves. Discourse: Studies in the Cultural Politics of Education, 27(2), 241-257.

Kramsch, C. J. (2009). The multilingual subject: What foreign language learners say about their experience and why it matters. Oxford, UK: Oxford University Press.

Lantolf, J., \& Pavlenko, A. (2001). (S)econd (L)anguage (A)ctivity theory: Understanding second language learners as people. In M. Breen (Ed.), Learner contributions to language learning: New directions in research (pp. 141-158). London, UK: Longman.

Lucca, L. di, Masiero, G., \& Pallotti, G. (2008). Language socialisation and language shift in the 1B generation: A study of Moroccan adolescents in Italy. International Journal of Multilingualism, 5(1), 53-72.

Matsumura, S. (2001). Learning the rules for offering advice: A quantitative approach to second language socialization. Language Learning, 51(4), 635-679.

Miller, J. (1999). Becoming audible: Social identity and second language use. Journal of Intercultural Studies, 20(2), $149-165$.

Miller, J. (2003). Audible difference: ESL and social identity in schools. Clevedon, UK: Cromwell Press.

Miller, J. (2004). Identity and language use: The politics of speaking ESL in schools. In A. Pavlenko \& A. Blackledge (Eds.), Negotiation of identities in multilingual contexts (pp. 290-315). Clevedon, UK: Cromwell Press.

Mitchell, J. C. (1984). Typicality and the case study. In R. F. Ellen (Ed.), Ethnographic research: A guide to general conduct (pp. 238-241). London, UK: Academic Press.

Montgomery, C. (2010). Understanding the international student experience. Hampshire, UK: Palgrave Macmillan.

Murphy-Lejeune, E. (2002). Student mobility and narrative in Europe: The new strangers. New York, NY: Routledge.

Nam, M. (2008). Second language writing socialization: Korean graduate students' use of resources in the U.S. academic context. (Unpublished dissertation). University of Cincinnati, Cincinnati, $\mathrm{OH}$. 
Noji, T. (2003). The socialization of Japanese ESL students into oral discourse practices at a United States university: A qualitative description. (Unpublished dissertation). Indiana University of Pennsylvania, Indiana, PA.

Norton (Peirce), B. (1995). Social identity, investment, and language learning. TESOL Quarterly, 29(1), 9-31.

Norton, B. (1998). Rethinking acculturation in second language acquisition. PROSPECT: Australian Journal of TESOL Associations, 13(2), 4-19.

Norton, B. (2000). Identity and language learning: Gender, ethnicity, and educational change. Essex, UK: Pearson.

Norton, B. (2001). Non-participation, imagined communities, and the language classroom. In M. Breen (Ed.), Learner contributions to language learning: New directions in research (pp. 159-171). London, UK: Longman.

Norton, B., \& Toohey, K. (2001). Changing perspectives on good language learners. TESOL Quarterly, 35(2), $307-322$.

Norton, B., \& Toohey, K. (2011). Identity, language learning, and social change. Language Teaching, 44(4), 412-446.

Ochs, E. (2001). Language socialization. In A. Duranti (Ed.), Key terms in language and culture (pp. 227-230). Oxford, UK: Blackwell.

Ochs, E. (2002). Becoming a speaker of culture. In C. J. Kramsch (Ed.), Language acquisition and language socialization: Ecological perspectives (pp. 99-120). London, UK: Continuum.

Ohta, A. S. (1999). Interactional routines and the socialization of interactional style in adult learners of Japanese. Journal of Pragmatics, 31(11), 1493-1512.

Ortaçtepe, D. (2012). The development of conceptual socialization in international students: A language socialization perspective on conceptual fluency and social identity. Cambridge, UK: Cambridge Scholarly Publishers.

Patton, M. (2001). Qualitative evaluation and research methods (3rd ed.). Newbury Park: Sage.

Pavlenko, A. (2002). Narrative study: Whose story is it, anyway? TESOL Quarterly, 36(2), 213-218.

Pavlenko, A. (2008). Narrative analysis in the study of bi- and multilingualism. In M. Moyer \& L. Wei (Eds.), The Blackwell guide to research methods in bilingualism (pp. 311-325). Oxford, UK: Blackwell.

Pavlenko, A., \& Blackledge, A. (2004). Introduction. In A. Pavlenko \& A. Blackledge (Eds.), Negotiation of identities in multilingual contexts (pp. 1-34). Clevedon, UK: Cromwell Press.

Pellegrino, V. A. (1998). Student perspectives on language learning in a study abroad context. Frontiers: The Interdisciplinary Journal of Study Abroad, 4, 91-120.

Polanyi, L. (1995). Language learning and living abroad: Stories from the field. In B. F. Freed (Ed.), Second language acquisition in a study abroad context (pp. 271-291). Philadelphia, PA: John Benjamins.

Ricento, T. (2005). Considerations of identity in L2 learning. In E. Hinkel (Ed.), Handbook of research in second language teaching and learning (pp. 895-911). Mahwah, NJ: Lawrence Erlbaum.

Schecter, S., \& Bayley, R. (2004). Language socialization in theory and practice. International Journal of Qualitative Studies in Education, 17(5), 605-625.

Schieffelin, B. B., \& Ochs, E. (1986). Language socialization across cultures. New York, NY: Cambridge University Press.

Schumann, J. H. (1986). Research on the acculturation model for second language acquisition. Journal of Multilingual and Multicultural Development, 7, 379-392.

Schumann, J. H. (1997). The neurobiology of affect in language. Oxford, UK: Blackwell.

Seidman, I. (1998). Interviewing as qualitative research (2nd ed.). New York, NY: Teachers College Press.

Shafak, E. (2004). The saint of incipient insanities. New York, NY: Farrar, Strauss and Giroux.

Siegal, M. (1996). The role of learner subjectivity in second language sociolinguistic competency: Western women learning Japanese. Applied Linguistics, 17(3), 356-382.

Swartz, D. (1997). Culture and power: The sociology of Pierre Bourdieu. Chicago, IL: University of Chicago Press.

Talmy, S. (2008). The cultural productions of the ESL student at Tradewinds High: Contingency, multidirectionality, and identity in L2 socialization. Applied Linguistics, 29(4), 619-644.

Wan, T. (1990). Factors associated with academic stress experienced by international students in U.S. universities: Testing a cognitive model of stress (Unpublished doctoral dissertation). State University of New York at the University at Albany, Albany, NY.

Wilkinson, S. (2000). Emerging questions about study abroad. ADFL Bulletin, 32(1), 36-41.

Wilkinson, S. (2002). The omnipresent classroom during summer study abroad: American students in conversation with their French hosts. The Modern Language Journal, 86, 157-173. 